\title{
Synthesis and structures of ruthenium-NHC complexes and their catalysis in hydrogen transfer reaction
}

\author{
Chao Chen ${ }^{1}$, Chunxin Lu ${ }^{2}$, Qing Zheng ${ }^{1}$, Shengliang Ni ${ }^{*}$, Min Zhang ${ }^{3}$ \\ and Wanzhi Chen*3
}

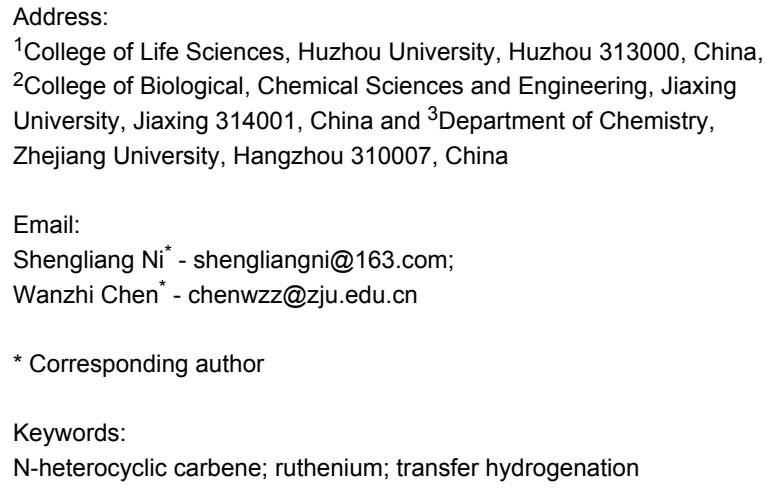

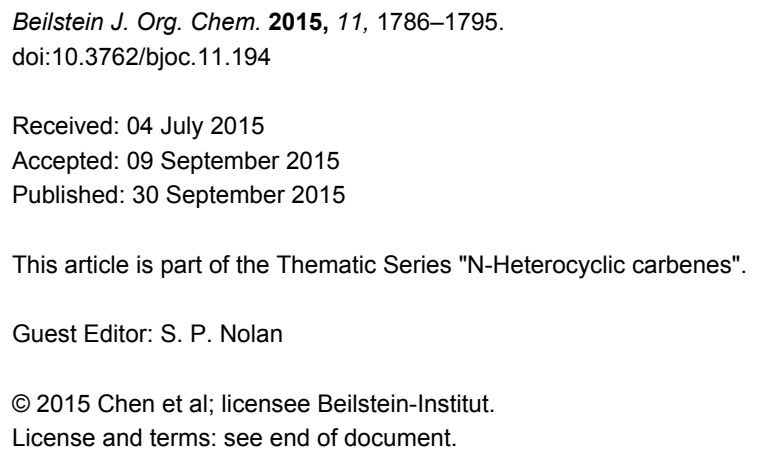

\begin{abstract}
Ruthenium complexes $\left[\mathrm{Ru}(\mathrm{L} 1)_{2}\left(\mathrm{CH}_{3} \mathrm{CN}\right)_{2}\right]\left(\mathrm{PF}_{6}\right)_{2}(\mathbf{1}),\left[\mathrm{RuL} 1\left(\mathrm{CH}_{3} \mathrm{CN}\right)_{4}\right]\left(\mathrm{PF}_{6}\right)_{2}(\mathbf{2})$ and $\left[\mathrm{RuL} 2\left(\mathrm{CH}_{3} \mathrm{CN}\right)_{3}\right]\left(\mathrm{PF}_{6}\right)_{2}(\mathbf{3})\left(\mathrm{L} 1=3-\mathrm{methyl}^{-}\right.$ 1-(pyrimidine-2-yl)imidazolylidene, L2 = 1,3-bis(pyridin-2-ylmethyl)benzimidazolylidene) were obtained through a transmetallation reaction of the corresponding nickel-NHC complexes with $\left[\mathrm{Ru}(p \text {-cymene })_{2} \mathrm{Cl}_{2}\right]_{2}$ in refluxing acetonitrile solution. The crystal structures of three complexes determined by X-ray analyses show that the central $\mathrm{Ru}(\mathrm{II})$ atoms are coordinated by pyrimidine- or pyridine-functionalized $\mathrm{N}$-heterocyclic carbene and acetonitrile ligands displaying the typical octahedral geometry. The reaction of $\left[\mathrm{RuL} 1\left(\mathrm{CH}_{3} \mathrm{CN}\right)_{4}\right]\left(\mathrm{PF}_{6}\right)_{2}$ with triphenylphosphine and 1,10-phenanthroline resulted in the substitution of one and two coordinated acetonitrile ligands and afforded $\left[\mathrm{RuL} 1\left(\mathrm{PPh}_{3}\right)\left(\mathrm{CH}_{3} \mathrm{CN}\right)_{3}\right]\left(\mathrm{PF}_{6}\right)_{2}(4)$ and $\left[\mathrm{RuL} 1(\mathrm{phen})\left(\mathrm{CH}_{3} \mathrm{CN}\right)_{2}\right]\left(\mathrm{PF}_{6}\right)_{2}(\mathbf{5})$, respectively. The molecular structures of the complexes $\mathbf{4}$ and $\mathbf{5}$ were also studied by X-ray diffraction analysis. These ruthenium complexes have proven to be efficient catalysts for transfer hydrogenation of various ketones.
\end{abstract}

\section{Introduction}

$\mathrm{N}-$ Heterocyclic carbenes (NHCs) have been recognized as a class of strong donating ligands which can stabilize various metal complexes of catalytic importance. Transition metal complexes bearing NHCs are more stable to air, moisture, heat, and tolerant toward oxidation compared to phosphine ligands [1-7]. Among NHCs, functionalized NHC ligands have been extensively studied in recent years because of their intriguing structural diversities and potential applications in coordination chemistry and homogenous catalysis. NHC ligands containing additional phosphine, nitrogen, oxygen, and sulfur donating groups [8-16] have been reported.

In the family of metal complexes supported by functionalized NHCs, ruthenium complexes have long been a research focus 
on various applications such as catalysis and photochemistry [17-26]. However, the majority of such ruthenium complexes often contain coordinated aromatic carbocycles [27-29]. In contrast, only a few examples $\mathrm{Ru}(\mathrm{II})$ complexes of functionalized NHCs containing easily dissociating acetonitrile ligands have been studied [30-32]. We have reported the synthesis of some pyridine- and phenanthrolin-functionalized Ru(II)-NHC complexes containing acetonitrile ligands $[33,34]$. The most notable example is the acetonitrile-coordinated dinuclear $\mathrm{Ru}(\mathrm{II})-\mathrm{NHC}$ complex derived from 3,6-bis( $\mathrm{N}$ (pyridylmethyl)imidazolylidenyl)pyridazine, which is a very efficient catalyst for the oxidation of alkenes [35]. In continuation of our studies on functionalized Ru(II)-NHC complexes containing acetonitrile ligands, we herein report the synthesis and characterization of three pyrimidine- and pyridine-functionalized NHC-ruthenium complexes containing two, four, and three acetonitrile ligands, respectively. These complexes show good catalytic activity in the transfer hydrogenation of ketones. The reaction of acetonitrile-coordinated Ru-NHC complex 2 with other donors such as triphenylphosphine and 1,10-phenanthroline was also studied.

\section{Results and Discussion Synthesis and characterization of $\left[\mathrm{Ru}(\mathrm{L} 1)_{2}\left(\mathrm{CH}_{3} \mathrm{CN}\right)_{2}\right]\left(\mathrm{PF}_{6}\right)_{2}(\mathbf{1})$, $\left[\mathrm{RuL} 1\left(\mathrm{CH}_{3} \mathrm{CN}\right)_{4}\right]\left(\mathrm{PF}_{6}\right)_{2}(2)$ and $\left[\mathrm{RuL} 2\left(\mathrm{CH}_{3} \mathrm{CN}\right)_{3}\right]\left(\mathrm{PF}_{6}\right)_{2}(3)$}

The ruthenium-NHC complexes $\mathbf{1}$ and $\mathbf{2}$ were synthesized by using the corresponding nickel-NHC complexes as the carbene transfer agent [36]. The reaction of imidazolium salt $\mathrm{HL} 1\left(\mathrm{PF}_{6}\right)$ (L1 = 3-methyl-1-(pyrimidine-2-yl)imidazolylidene) with
Raney nickel afforded the nickel-NHC complexes which were not isolated [30]. The subsequent reaction of the generated nickel-NHC complexes with a quarter equivalent of $[\mathrm{Ru}(p$ cymene) $\left.\mathrm{Cl}_{2}\right]_{2}$ in refluxing acetonitrile solution afforded bisNHC complex $\left[\mathrm{Ru}(\mathrm{L} 1)_{2}\left(\mathrm{CH}_{3} \mathrm{CN}\right)_{2}\right]\left(\mathrm{PF}_{6}\right)_{2}(\mathbf{1})$ in a yield of $76 \%$ (Scheme 1). When a half equivalent of $\left[\mathrm{Ru}(p \text {-cymene }) \mathrm{Cl}_{2}\right]_{2}$ and an excess of $\mathrm{NH}_{4} \mathrm{PF}_{6}$ were employed under the same conditions, the reaction afforded the mono-NHC complex $\left[\mathrm{RuL} 1\left(\mathrm{CH}_{3} \mathrm{CN}\right)_{4}\right]\left(\mathrm{PF}_{6}\right)_{2}(2)$ in $53 \%$ yield. It is worth noting that most of the structurally characterized acetonitrile complexes are obtained through the reaction of halides with silver complexes $\left(\mathrm{AgPF}_{6}\right.$ or $\left.\mathrm{AgBF}_{4}\right)$ in acetonitrile solution [20]. The reaction in refluxing acetonitrile is more convenient than the above mentioned procedure. The formulations of complexes $\mathbf{1}$ and $\mathbf{2}$ were first characterized by NMR measurements and further confirmed by elemental analysis and X-ray diffraction. In the ${ }^{1} \mathrm{H}$ NMR spectra of complexes $\mathbf{1}$ and $\mathbf{2}$, disappearance of the resonances assigned to the imidazolium acidic $\mathrm{CH}$ and $p$-cymene protons were observed. The acetonitrile protons of complex 1 were found at $2.41 \mathrm{ppm}$ as a singlet. However, the protons of acetonitrile ligands of complex 2 were found at 2.52, 2.12 , and $1.96 \mathrm{ppm}$ as three singlets. This illustrates that the three acetonitrile ligands in complex $\mathbf{2}$ are magnetic unequivalent. The ${ }^{13} \mathrm{C}$ NMR spectra of $\mathbf{1}$ and $\mathbf{2}$ exhibit resonance signals at 193.1 and $193.0 \mathrm{ppm}$ ascribed to the carbenic carbons.

The ruthenium-NHC complexes $\mathbf{1}$ and $\mathbf{2}$ are stable in air and under light irradiation. Single crystals suitable for X-ray diffraction could be obtained by slow diffusion of $\mathrm{Et}_{2} \mathrm{O}$ into $\mathrm{CH}_{3} \mathrm{CN}$ solutions and the detailed structure of $\mathbf{1}$ is depicted in Figure 1. In complex $\mathbf{1}$, the central ruthenium ion is hexacoordinated by two bidentate NHC ligands and two acetonitrile ligands in an
1) Raney nickel

2) 0.25 equiv $\left[(p \text {-cymene }) \mathrm{RuCl}_{2}\right]_{2}$ reflux overnight<smiles></smiles>

1) Raney nickel

2) 0.5 equiv $\left[(p \text {-cymene }) \mathrm{RuCl}_{2}\right]_{2}$ 1.5 equiv $\mathrm{NH}_{4} \mathrm{PF}_{6}$ reflux overnight

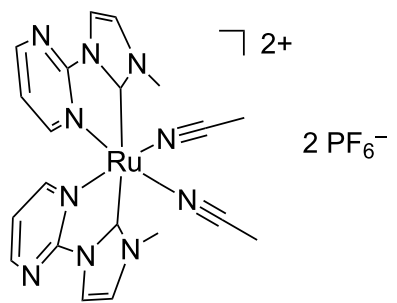

1, $76 \%$

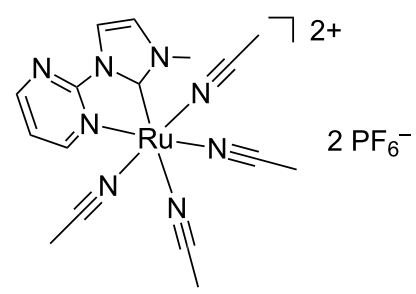

2, $53 \%$ 
octahedral geometry. One NHC ligand, one acetonitrile ligand and one carbon atom of the other NHC ligand occupy the equatorial plane in which two carbon atoms of two NHC ligands are mutually trans-arranged. The remaining acetonitrile ligand and one nitrogen atom of the NHC ligand lie on the axial positions. The angles $(\mathrm{N}-\mathrm{Ru}-\mathrm{N})$ of adjacent nitrogen atoms and $\mathrm{Ru}(\mathrm{II})$ ion are in the range of 83.9 to $94.0^{\circ}$. The $\mathrm{Ru}-\mathrm{C}$ distance $(2.066 \AA)$ is consistent with the reported values in known $\mathrm{Ru}-\mathrm{NHC}$ complexes [17-29]. The $\mathrm{Ru}-\mathrm{N}_{\text {pyrimidine }}$ distance $(2.081 \AA)$ is slightly longer than $\mathrm{Ru}-\mathrm{N}_{\text {acetonitrile }}(2.033 \AA)$.

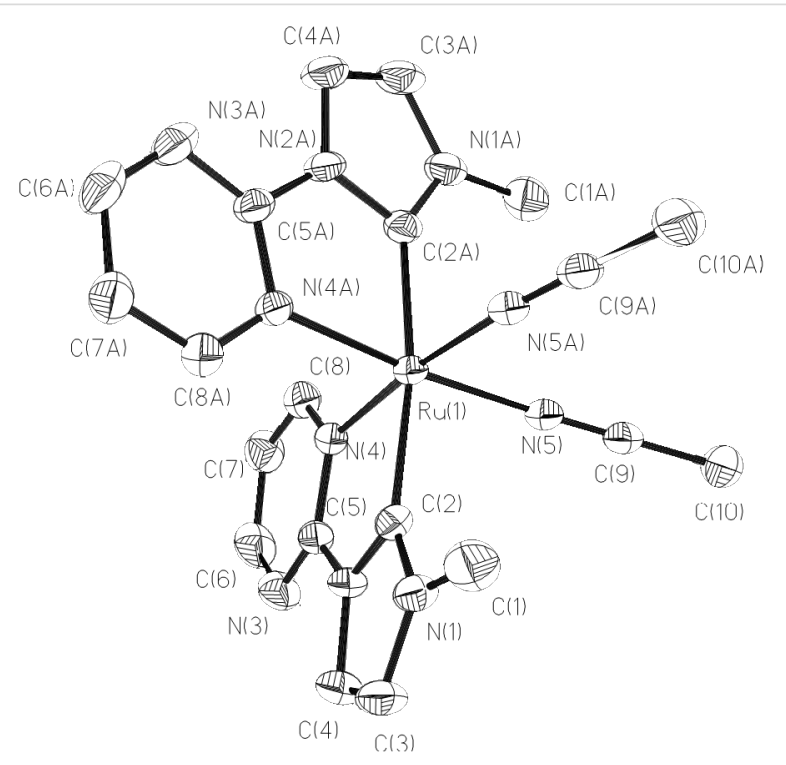

Figure 1: Structural view of 1 showing $30 \%$ thermal ellipsoids. All hydrogen atoms and $\mathrm{PF}_{6}{ }^{-}$were omitted for clarity. Selected bond lengths $(\AA)$ and angles (deg): $\mathrm{Ru}(1)-\mathrm{N}(5)$ 2.033(4), $\mathrm{Ru}(1)-\mathrm{C}(2)$ 2.066(5), Ru(1)-N(4) 2.081(4), N(5)\#1-Ru(1)-N(5) 83.9(2), $\mathrm{N}(5)-\mathrm{Ru}(1)-\mathrm{C}(2)$ 87.87(16), C(2)\#1-Ru(1)-C(2) 171.2(3), $\mathrm{N}(5)-\mathrm{Ru}(1)-\mathrm{N}(4)$ 91.12(16), C(2)\#1-Ru(1)-N(4) 95.88(17), $\mathrm{N}(5)-\mathrm{Ru}(1)-\mathrm{N}(4) \# 1$ 174.20(14). Symmetry code: \#1-x, y, -z+1/2.

The cationic structure of $\mathbf{2}$ is shown in Figure 2. The central $\mathrm{Ru}(\mathrm{II})$ ion is surrounded by one pyrimidine-functionalized NHC ligand and four acetonitrile ligands also in a typical octahedral geometry. The $\mathrm{Ru}$ ion lies on a twofold axis. The bidentate NHC ligand and two cis-arranged acetonitrile molecules form a
$\mathrm{Ru}(\mathrm{L} 1)\left(\mathrm{CH}_{3} \mathrm{CN}\right)_{2}$ plane, whereas the other two acetonitrile molecules occupy the axial positions. The bond length of $\mathrm{Ru}-\mathrm{C}_{\mathrm{NHC}}$ is $1.989 \AA$, which is slightly shorter than those found in $\mathrm{Ru}-\mathrm{NHC}$ complexes [12-18] and in complex $\mathbf{1}$. The bond distance of $\mathrm{Ru}-\mathrm{N}_{\text {acetonitrile }}(2.113 \AA)$ at the trans-position of the carbene ligand is longer than the other three $\mathrm{Ru}-\mathrm{N}_{\text {acetonitrile }}$ bonds $\left(2.023-2.033 \AA\right.$ ) and the $\mathrm{Ru}-\mathrm{N}_{\text {pyrimidine }}(2.064 \AA)$.

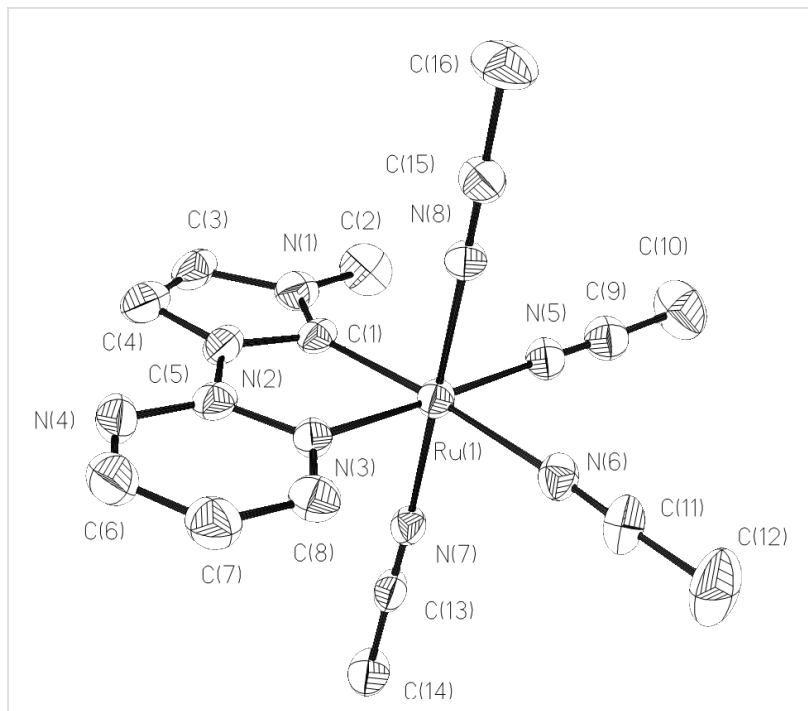

Figure 2: Structural view of 2 showing $30 \%$ thermal ellipsoids. All hydrogen atoms and $\mathrm{PF}_{6}{ }^{-}$were omitted for clarity. Selected bond lengths $(\AA)$ and angles (deg): $\mathrm{Ru}(1)-\mathrm{C}(2)$ 1.989(7), Ru(1)-N(5) 2.023(5), $\mathrm{Ru}(1)-\mathrm{N}(8)$ 2.027(5), $\mathrm{Ru}(1)-\mathrm{N}(7)$ 2.033(6), $\mathrm{Ru}(1)-\mathrm{N}(4)$ 2.064(5), Ru(1)-N(6) 2.113(6), C(2)-Ru(1)-N(5) 88.3(2),

$\mathrm{C}(2)-\mathrm{Ru}(1)-\mathrm{N}(8)$ 91.2(2), N(5)-Ru(1)-N(8) 179.3(2), C(2)-Ru(1)-N(7) 99.8(3).

Similarly, the reaction of the in situ generated nickel-NHC complex from imidazolium salt HL2 $\left(\mathrm{PF}_{6}\right)(\mathrm{L} 2=1,3-$ bis(pyridin-2-ylmethyl)benzimidazolylidene) with a half equivalent of $\left[\mathrm{Ru}(p \text {-cymene }) \mathrm{Cl}_{2}\right]_{2}$ and an excess of $\mathrm{NH}_{4} \mathrm{PF}_{6}$ in a refluxing acetonitrile solution afforded the tri-acetonitrile coordinated $\mathrm{Ru}(\mathrm{II})-\mathrm{NHC}$ complex $\left[\mathrm{RuL} 2\left(\mathrm{CH}_{3} \mathrm{CN}\right)_{3}\right]\left(\mathrm{PF}_{6}\right)_{2}$ (3) in a yield of $61 \%$ (Scheme 2). The formation of 3 was also confirmed by the ${ }^{1} \mathrm{H}$ NMR and ${ }^{13} \mathrm{C}$ NMR spectra. The ${ }^{1} \mathrm{H}$ NMR spectrum of $\mathbf{3}$ shows characteristic resonance signals due to the<smiles></smiles>

1) Raney nickel

2) 0.5 equiv $\left[(p \text {-cymene }) \mathrm{RuCl}_{2}\right]_{2}$ 1.5 equiv $\mathrm{NH}_{4} \mathrm{PF}_{6}$ reflux overnight

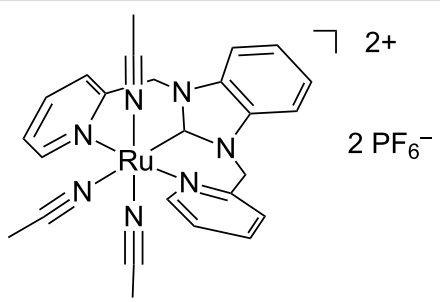

3, $61 \%$ 
pyridyl, methylene, benzimidazolylidene and acetonitrile groups. The absence of a benzimidazole acidic $\mathrm{C} 2-\mathrm{H}$ proton illustrates the formation of the $\mathrm{Ru}-\mathrm{C}$ bond. The acetonitrile protons appear at 2.35 and $2.08 \mathrm{ppm}$ as two singlets. The ${ }^{13} \mathrm{C}$ NMR spectrum of $\mathbf{3}$ exhibits a resonance peak at $190 \mathrm{ppm}$, which is ascribed to the carbenic carbon atom. Complex $\mathbf{3}$ has been further identified by X-ray crystallography and the cationic structure of molecular $\mathbf{3}$ is depicted in Figure 3. The ruthenium ion is coordinated by a tridentate pincer NHC ligand and three acetonitrile ligands also in an octahedral geometry. The symmetrical pincer-type NCN ligand and an acetonitrile ligand occupy the equatorial plane and the remaining two acetonitrile ligands are located at the axial positions. The $\mathrm{N}-\mathrm{Ru}-\mathrm{N}$ angles of the three acetonitrile ligands and the $\mathrm{Ru}(\mathrm{II})$ ion are $86.03,89.12$ and $174.99^{\circ}$, respectively. Similar to complex 2 , the bond distance of $\mathrm{Ru}-\mathrm{N}_{\text {acetonitrile }}(2.130 \AA)$ at the trans-position of the carbene ligand is slightly longer than the other bond distances of $\mathrm{Ru}-\mathrm{N}_{\text {acetonitrile }}(2.030$ and $2.028 \AA$ ) and the $\mathrm{Ru}-\mathrm{C}$ $(1.947 \AA)$ is shorter than that of many known $\mathrm{Ru}-\mathrm{C}_{\text {carbene }}$ distances [17-29].

\section{Catalytic transfer hydrogenation reaction}

Ruthenium-NHC complexes are known to be efficient catalysts for transfer hydrogenation reactions [23,37-39]. The ruthenium-NHC complexes presented above are stabilized by strong $\mathrm{Ru}$-carbene bonds and contain 2-4 easily dissociating acetonitrile molecules, and are thus ideal catalysts. We tested

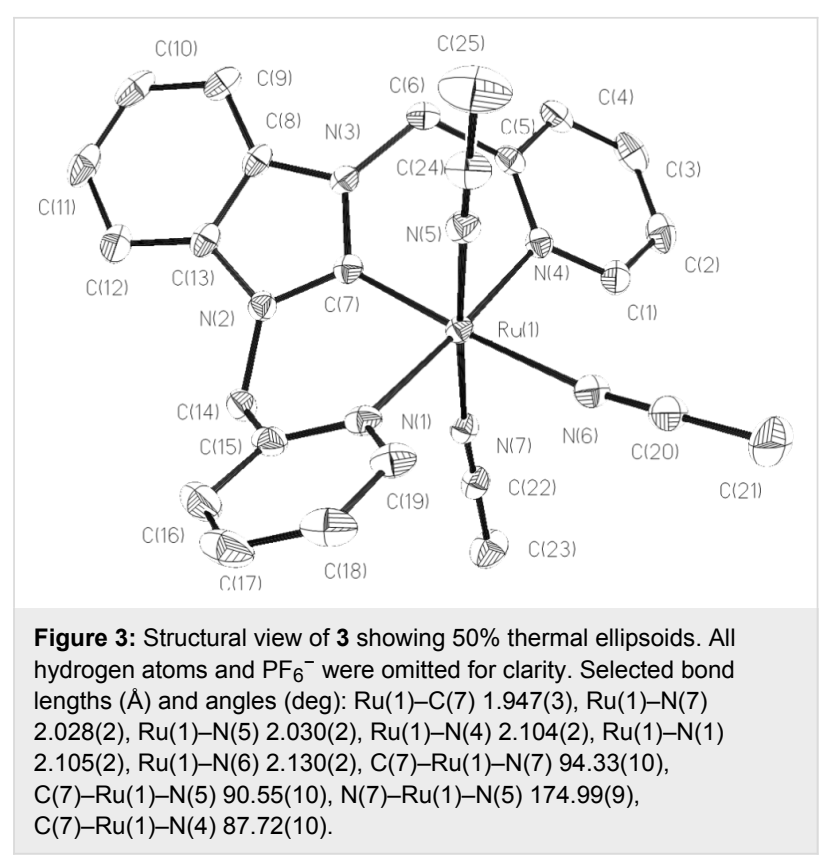

their catalytic activities for transfer hydrogenation of ketones. Firstly, acetophenone was selected as the model substrate to evaluate the catalytic activities of complexes 1-3. The standard experiment was carried out at $80{ }^{\circ} \mathrm{C}$ with varied $\mathrm{Ru}$ loadings from 1 to $0.01 \mathrm{~mol} \%$ and the results are summarized in Table 1. The reaction profiles show that acetophenone could be reduced to 1-phenylethanol in $89-99 \%$ yield within $0.5 \mathrm{~h}$ using

Table 1: Catalytic activities of 1-3 in transfer hydrogenation of acetophenone. ${ }^{a}$

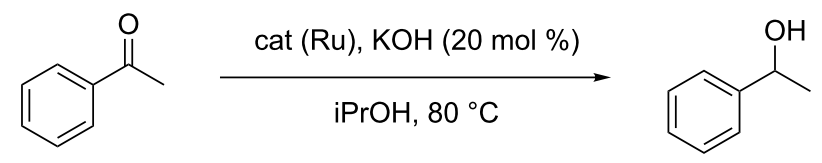

\begin{tabular}{|c|c|c|c|c|c|}
\hline Entry & Catalyst & Catalyst (mol \%) & Time (h) & Yield $(\%)^{b}$ & TON/TOF $\left(\mathrm{h}^{-1}\right)$ \\
\hline 1 & \multirow{4}{*}{1} & 1 & 0.5 & 89 & $89 / 172$ \\
\hline 2 & & 0.1 & 0.5 & 79 & $790 / 1580$ \\
\hline 3 & & 0.1 & 1 & 92 & $920 / 920$ \\
\hline 4 & & 0.01 & 3 & 90 & $9000 / 3000$ \\
\hline 5 & \multirow{4}{*}{2} & 1 & 0.5 & 99 & $99 / 198$ \\
\hline 6 & & 0.1 & 0.5 & 86 & $860 / 1720$ \\
\hline 7 & & 0.1 & 1 & 99 & $990 / 990$ \\
\hline 8 & & 0.01 & 3 & 97 & $9700 / 3233$ \\
\hline 9 & \multirow{4}{*}{3} & 1 & 0.5 & 99 & $99 / 198$ \\
\hline 10 & & 0.1 & 0.5 & 89 & $890 / 1780$ \\
\hline 11 & & 0.1 & 1 & 99 & $990 / 990$ \\
\hline 12 & & 0.01 & 3 & 96 & $9600 / 3200$ \\
\hline
\end{tabular}

${ }^{\mathrm{a} C}$ Conditions: acetophenone $(1.00 \mathrm{mmol}), \mathrm{KOH}(20 \mathrm{~mol} \%)$, and catalyst $(1-0.01 \mathrm{~mol} \%)$ in $3 \mathrm{~mL}$ of iPrOH at $80{ }^{\circ} \mathrm{C}$. ${ }^{\mathrm{b}} \mathrm{The}$ yields of products were detected by GC. 
$1 \mathrm{~mol} \%$ of the Ru catalysts (Table 1, entries 1, 5 and 9). When the amount of catalysts is decreased to $0.1 \mathrm{~mol} \%$, the corresponding conversion still reached 79-89\% (Table 1, entries 2, 6 and 10). 1-Phenylethanol could also be obtained in excellent yields using $0.1 \mathrm{~mol} \%$ and $0.01 \mathrm{~mol} \% \mathrm{Ru}$ catalysts when the reaction time was extended to 1 and $3 \mathrm{~h}$, respectively (Table 1, entries $3,7,11$ and 4, 8, 12). At catalyst loadings of $0.01 \mathrm{~mol} \%$, TOF of $\mathbf{1}-\mathbf{3}$ are 3000,3233 , and $3200 \mathrm{~h}^{-1}$ for transfer hydrogenation of acetophenone which are nearly identical to that of $\left[\mathrm{Ru}\left({ }^{\mathrm{Me}} \mathrm{CC}^{\text {meth }}\right)_{2}\left(\mathrm{CH}_{3} \mathrm{CN}\right)_{2}\right]\left(\mathrm{BF}_{4}\right)_{2}\left({ }^{\mathrm{Me}} \mathrm{CC}{ }^{\text {meth }}=\right.$ 1,1'-dimethyl-3,3'-methylene-diimidazol-2,2'-diylidene) [40]. Ruthenium picolyl-NHC complex $\left[\left(\eta^{5}-\mathrm{C}_{5} \mathrm{Me}_{5}\right)-\right.$ $\left.\mathrm{Ru}(\mathrm{L})\left(\mathrm{CH}_{3} \mathrm{CN}\right)\right]\left[\mathrm{PF}_{6}\right]$ (L = 3-methyl-1-(2-picolyl)imidazol-2ylidene) is so far one of the most efficient catalyst for transfer hydrogenation of acetophenone which gave 1-phenylethanol in a conversion of $93 \%$ with a catalyst loading of $0.1 \mathrm{~mol} \%$ $[20,41]$. When the same amount of complexes 1-3 was used, the reaction gave 1-phenylethanol in $89 \%, 99 \%$ and $99 \%$ yields, respectively. These data illustrate that complexes $\mathbf{1}-\mathbf{3}$ are all quite active catalysts for transfer hydrogenation reactions. It seems that complexes $\mathbf{2}$ and $\mathbf{3}$ are a bit better than $\mathbf{1}$ for this transformation. The trans-effect of carbene ligand may promote the substitution of trans-positioned acetonitrile ligand by other substrates in the catalytic reaction.

Since complexes $\mathbf{2}$ and $\mathbf{3}$ are found to be the efficient catalysts for transfer hydrogenation of acetophenone, we further explored their catalytic potential in the reduction of other aromatic and aliphatic ketones. The reaction conditions are similar as those described in the transfer hydrogenation of acetophenone and $0.1 \mathrm{~mol} \%$ of Ru catalyst is utilized. The obtained results are given in Table 2. Complexes $\mathbf{2}$ and $\mathbf{3}$ are found to be very active in transfer hydrogenation of cyclohexanone, and cyclohexanol are almost quantitatively yielded within $0.5 \mathrm{~h}$ (Table 2, entries 1 and 2). The catalyst systems are also found to be good for the reduction of aromatic ketones bearing electron-withdrawing substituents (Table 2, entries 3-8) and electron-donating groups (Table 2, entries 9 and 10), and the target product could be obtained in excellent yields (90-99\%). Bulkier aromatic ketone benzophenone is also tested in this reaction with $92 \%$ and $94 \%$ conversion after $3 \mathrm{~h}$ (Table 2, entries 11 and 12). In addition, it is worth mentioning that the two ruthenium complexes exhibited a high tolerance towards sulfur species, 2-acetylthiophene is efficiently hydrogenated (Table 2, entries 13 and 14) with an increased reaction time of $3 \mathrm{~h}$.

\section{Reactions of tetra-acetonitrile $\mathrm{Ru}(\mathrm{II})-\mathrm{NHC}$ complex 2 with triphenylphosphine and 1,10-phenanthroline}

The coordinated acetonitrile ligands could be easily replaced by various $N$ - and $P$-donors [22]. The reactions of the acetonitrile-
Table 2: Transfer hydrogenation using complexes 2 and 3.

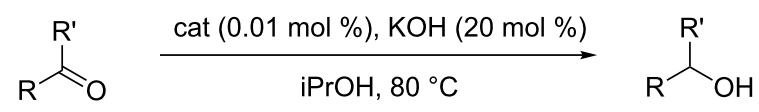

\begin{tabular}{|c|c|c|c|c|}
\hline Entry & Substrate & Catalyst & Time (h) & Yield $(\%)^{b}$ \\
\hline 1 & & 2 & 0.5 & 99 \\
\hline 2 & & 3 & 0.5 & 99 \\
\hline 3 & & 2 & 1 & 99 \\
\hline 4 & & 3 & 1 & 98 \\
\hline 5 & & 2 & 1 & 99 \\
\hline 6 & & 3 & 1 & 97 \\
\hline
\end{tabular}

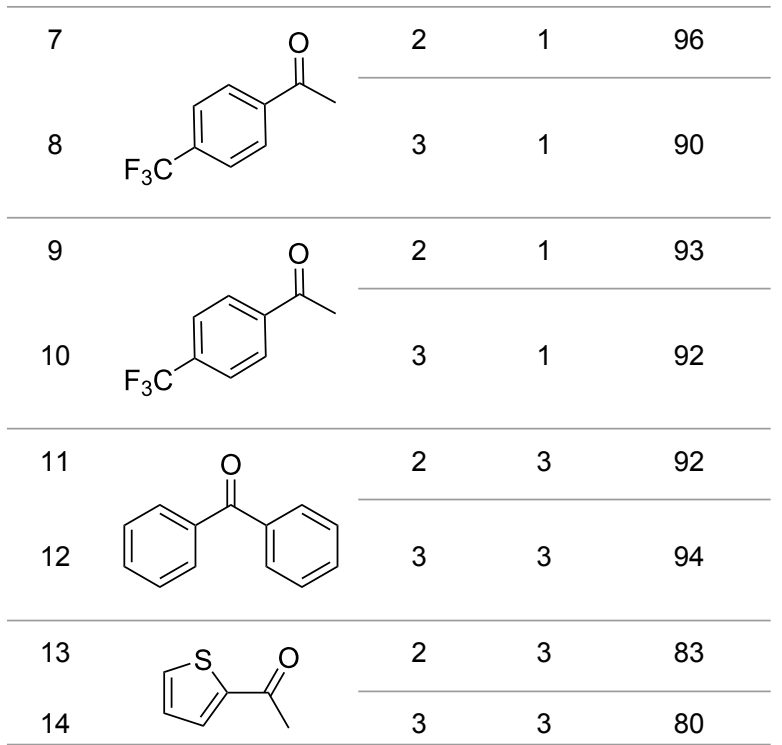

aConditions: substrate $(1.00 \mathrm{mmol}), \mathrm{KOH}(20 \mathrm{~mol} \%)$, catalyst $(0.1 \mathrm{~mol} \%)$ in $3 \mathrm{~mL}$ of $\mathrm{iPrOH}$ at $80^{\circ} \mathrm{C}$. ${ }^{\mathrm{b}} \mathrm{The}$ yields of products were detected by GC.

coordinated $\mathrm{Ru}-\mathrm{NHC}$ complexes with other ligands were studied. The reaction of complex 2 with an excess of triphenylphosphine and 1,10-phenanthroline in heat acetonitrile solution afforded $\mathbf{4}$ and 5, respectively. Even excess triphenylphosphine and 1,10-phenanthroline were used, only one and two coordinated acetonitrile ligands were substituted in complexes $\mathbf{4}$ and $\mathbf{5}$. Crystallization by slow diffusion of diethyl ether into their acetonitrile solutions gave $\mathbf{4}$ as a yellow solid in $40 \%$ yield and $\mathbf{5}$ as an orange yellow solid in $63 \%$ yield (Scheme 3 ). The yields of complexes $\mathbf{4}$ and $\mathbf{5}$ are relatively lower than complexes 1-3, but 

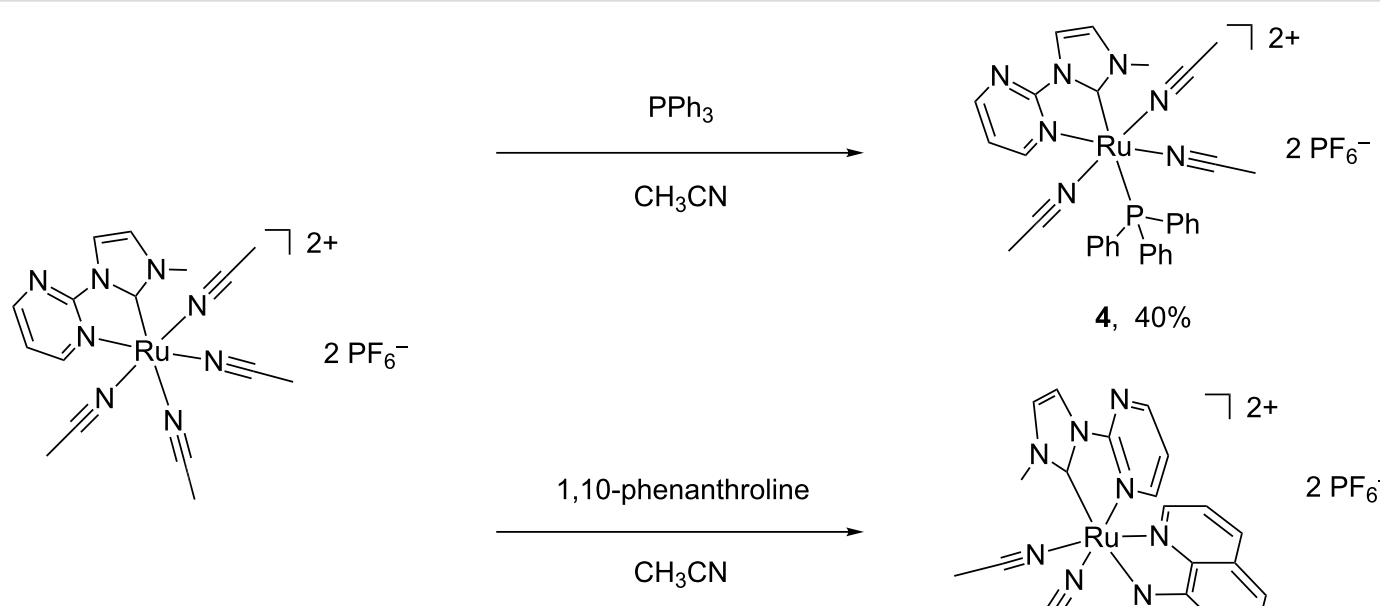

4, $40 \%$

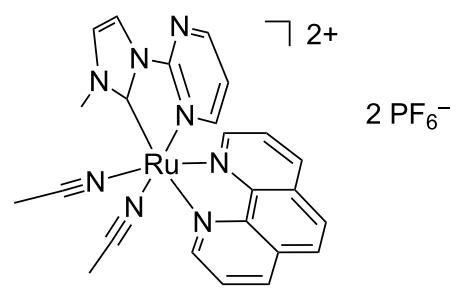

5, $63 \%$

Scheme 3: Synthesis of complexes 4 and 5.

still in the normal range as compared with the similar reaction [33]. In the ${ }^{1} \mathrm{H}$ NMR of $\mathbf{4}$, singlets at 2.14 and $2.07 \mathrm{ppm}$ are ascribed to three $\mathrm{CH}_{3} \mathrm{CN}$ ligands, and the rest peaks are belonged to NHC and triphenylphosphine ligand. ${ }^{1} \mathrm{H}$ NMR investigation of $\mathbf{5}$ suggests that complex $\mathbf{5}$ contains one NHC ligand, one phenanthroline ligand and two acetonitrile ligands. The $\mathrm{CH}_{3} \mathrm{CN}$ protons of 5 are founded at 2.53 and $2.28 \mathrm{ppm}$. In the ${ }^{13} \mathrm{C}$ NMR, the carbene carbons of complexes 4 and 5 are found at 190 and $200 \mathrm{ppm}$, respectively.

The structures of $\mathbf{4}$ and $\mathbf{5}$ determined by X-ray diffraction analysis are shown in Figure 4 and Figure 5. In the cationic structure of $\mathbf{4}$, the acetonitrile ligand at the trans-position of the NHC is substituted by a triphenylphosphine ligand. The CNPN atoms form the equatorial plane. The other two acetonitrile ligands are still trans-arranged at the axial positions. The $\mathrm{P}-\mathrm{Ru}-\mathrm{N}$ angles of three acetonitrile ligands and pyrimidine are 92.91, 92.06, 88.91, and 98.34 ${ }^{\circ}$. The $\mathrm{Ru}-\mathrm{C}$ bond distances being $2.039 \AA$ is slightly longer than those of $\mathbf{2}$ and $\mathbf{3}$, but similar to complex $\mathbf{1}$. The $\mathrm{Ru}-\mathrm{P}$ bond distance is $2.4080 \AA$, which are no difference from those of reported $\mathrm{Ru}(\mathrm{II})$ complexes [3,4]. In complex $\mathbf{5}$, the central $\mathrm{Ru}$ ion is coordinated by one NHC ligand, one 1,10-phenanthroline ligand and two acetonitrile molecules. The NHC ligand, one acetonitrile ligand and one nitrogen atom of phenanthroline occupy the equatorial plane in which the carbon atom of NHC ligand is trans to the nitrogen atom of phenanthroline with the $\mathrm{C}(2)-\mathrm{Ru}(1)-\mathrm{N}(6)$ angle of $169.08^{\circ}$, the acetonitrile molecule is trans to the pyrimidine group with the $\mathrm{N}(8)-\mathrm{Ru}(1)-\mathrm{N}(1)$ angle of $176.42^{\circ}$. The rest coordination nitrogen atoms of acetonitrile and phenanthroline lie on the axial positions with the $\mathrm{N}(7)-\mathrm{Ru}(1)-\mathrm{N}(5)$ angle of $173.74^{\circ}$.

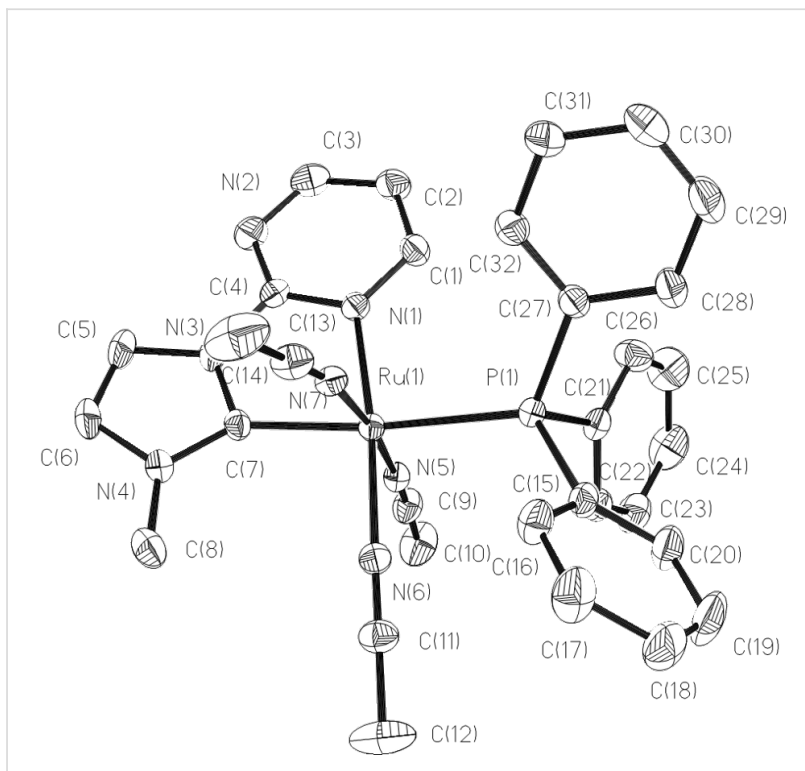

Figure 4: Structural view of 4 showing $30 \%$ thermal ellipsoids. All hydrogen atoms and $\mathrm{PF}_{6}{ }^{-}$were omitted for clarity. Selected bond lengths $(\AA)$ and angles (deg): $\mathrm{Ru}(1)-\mathrm{N}(5)$ 2.012(4), $\mathrm{Ru}(1)-\mathrm{N}(7)$ 2.020(4), Ru(1)-N(6) 2.025(4), Ru(1)-C(7) 2.039(4), Ru(1)-N(1) 2.120(4), Ru(1)-P(1) 2.4080(11), N(5)-Ru(1)-N(7) 173.83(16), $\mathrm{N}(5)-\mathrm{Ru}(1)-\mathrm{N}(6)$ 87.01(16), N(7)-Ru(1)-N(6) 89.42(15), $\mathrm{N}(5)-\mathrm{Ru}(1)-\mathrm{C}(7)$ 92.27(17), N(5)-Ru(1)-P(1) 92.91(11), C(7)-Ru(1)-P(1) 173.12(16).

\section{Conclusion}

In summary, $\mathrm{Ru}-\mathrm{NHC}$ complexes bearing pyrimidine- and pyridine-functionalized NHC ligands have been prepared through a carbene transfer reaction using nickel-NHC as the carbene source. Their structures have been definitely determined by X-ray crystallography. The catalytic behavior of di-, tetra- and 


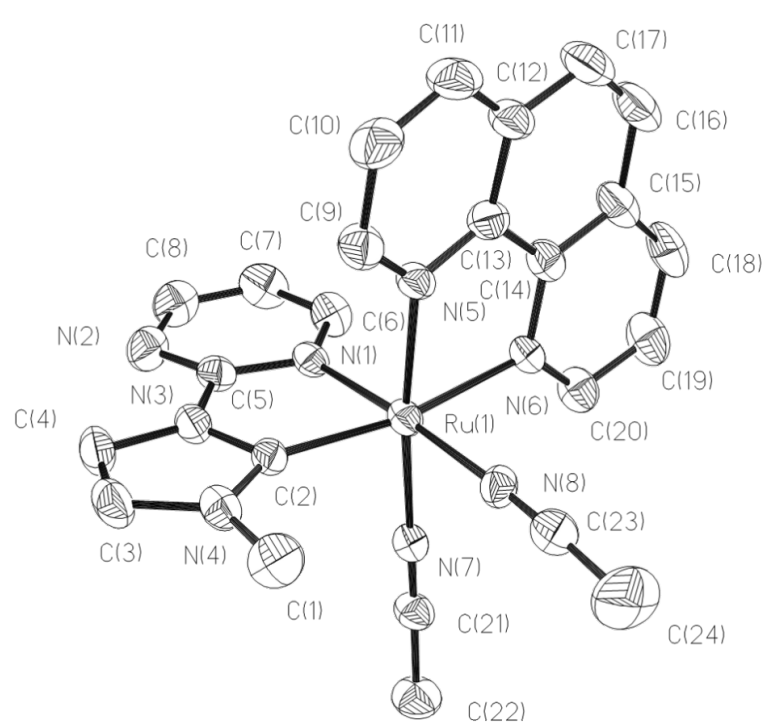

Figure 5: Structural view of 5 showing $30 \%$ thermal ellipsoids. All hydrogen atoms and $\mathrm{PF}_{6}{ }^{-}$were omitted for clarity. Selected bond lengths $(\AA)$ and angles (deg): $\mathrm{Ru}(1)-\mathrm{C}(2)$ 2.007(5), $\mathrm{Ru}(1)-\mathrm{N}(8)$ 2.022(4) Ru(1)-N(7) 2.049(4), Ru(1)-N(5) 2.063(4), Ru(1)-N(1) 2.077(4), Ru(1)-N(6) 2.126(4), C(2)-Ru(1)-N(8) 99.06(18), $\mathrm{C}(2)-\mathrm{Ru}(1)-\mathrm{N}(7)$ 91.10(17), N(8)-Ru(1)-N(7) 87.76(16), $\mathrm{C}(2)-\mathrm{Ru}(1)-\mathrm{N}(5)$ 95.03(17), N(8)-Ru(1)-N(5) 90.05(16), $\mathrm{N}(7)-\mathrm{Ru}(1)-\mathrm{N}(5)$ 173.74(16). Symmetry code: \#1 $\mathrm{x},-\mathrm{y}+3 / 2, \mathrm{z}$.

tri-acetonitrile-coordinated ruthenium complexes in transfer hydrogenation reactions was studied. These ruthenium complexes were found to be highly efficient catalysts for transfer hydrogenation of ketones. The catalytic properties of the ruthenium complexes in other organic transformation will be further studied.

\section{Experimental}

All chemicals were obtained from commercial suppliers in reagent grade quality and were used as received. $\mathrm{HL}_{1} \mathrm{PF}_{6}$ and $\mathrm{HL}_{2} \mathrm{PF}_{6}$ were synthesized according to the reported method $[42,43] .{ }^{1} \mathrm{H}$ and ${ }^{13} \mathrm{C}$ NMR spectra were recorded on a Bruker Avance-400 (400 MHz) spectrometer operating at $400 \mathrm{MHz}$ for ${ }^{1} \mathrm{H}$ and at $100 \mathrm{MHz}$ for ${ }^{13} \mathrm{C}$. Chemical shifts $(\delta)$ were expressed in ppm downfield to TMS at $\delta=0 \mathrm{ppm}$ and coupling constants $(J)$ were expressed in $\mathrm{Hz}$. Elemental analyses were performed by a Flash EA 1112 ThermoFinnigan analyzer.

Synthesis of $\left[\mathrm{Ru}(\mathrm{L1})_{2}\left(\mathrm{CH}_{3} \mathrm{CN}\right)_{2}\right]\left(\mathrm{PF}_{6}\right)_{2}$ (1). A mixture of $\mathrm{HL} 1\left(\mathrm{PF}_{6}\right)$ (306 mg, $1.0 \mathrm{mmol}$ ), excess Raney nickel (500 mg) in $10 \mathrm{~mL} \mathrm{MeCN}$ was stirred at $80{ }^{\circ} \mathrm{C}$ for $24 \mathrm{~h}$. After it was cooled to room temperature, the solution was filtered through Celite. Then $\left[\mathrm{Ru}(p \text {-cymene }) \mathrm{Cl}_{2}\right]_{2}(153 \mathrm{mg}, 0.25 \mathrm{mmol})$ was added to the solution and stirred at reflux for $12 \mathrm{~h}$. After filtration through a plug of Celite, the mixture was concentrated and poured into $\mathrm{Et}_{2} \mathrm{O}(30 \mathrm{~mL})$ to precipitate the product. Compound $\mathbf{1}$ was obtained as a yellow solid. Yield: $307 \mathrm{mg}, 76 \%$. Anal. calcd for $\mathrm{C}_{20} \mathrm{H}_{22} \mathrm{~F}_{12} \mathrm{~N}_{10} \mathrm{P} 2 \mathrm{Ru}$ : C, 30.27; H, 2.79; N, 17.65; found: C, 30.19; H, 2.82; N, 17.55; ${ }^{1} \mathrm{H}$ NMR (400 MHz, DMSO- $\left.d_{6}\right) \delta 8.77\left(\mathrm{~d}, J=4.8 \mathrm{~Hz}, \mathrm{C}_{4} \mathrm{H}_{3} \mathrm{~N}_{2}\right.$, $2 \mathrm{H}), 8.31\left(\mathrm{~d}, J=2.0 \mathrm{~Hz}, \mathrm{C}_{3} \mathrm{H}_{2} \mathrm{~N}_{2}, 2 \mathrm{H}\right), 8.09$ (d, $J=4.8 \mathrm{~Hz}$, $\left.\mathrm{C}_{4} \mathrm{H}_{3} \mathrm{~N}_{2}, 2 \mathrm{H}\right), 7.90\left(\mathrm{~d}, J=2.0 \mathrm{~Hz}, \mathrm{C}_{4} \mathrm{H}_{3} \mathrm{~N}_{2}, 2 \mathrm{H}\right), 7.27$ (t, $J=$ $\left.4.8 \mathrm{~Hz}, \mathrm{C}_{4} \mathrm{H}_{3} \mathrm{~N}_{2}, 2 \mathrm{H}\right), 4.17$ (s, $\left.\mathrm{CH}_{3}, 3 \mathrm{H}\right), 2.41$ (s, $\left.\mathrm{CH}_{3} \mathrm{CN}, 6 \mathrm{H}\right)$; ${ }^{13} \mathrm{C}$ NMR (100 MHz, DMSO- $\left.d_{6}\right) \delta 193.1(\mathrm{Ru}-C), 166.2,159.8$, 158.7, 128.6, 127.0, 120.0, 117.9, 37.7, 4.17.

Synthesis of $\left[\mathrm{RuL1}\left(\mathrm{CH}_{3} \mathrm{CN}\right)_{4}\right]\left(\mathrm{PF}_{6}\right)_{2}$ (2). A mixture of HL1 $\left(\mathrm{PF}_{6}\right)$ (153 mg, $0.5 \mathrm{mmol}$ ), excess Raney nickel (300 mg) in $10 \mathrm{~mL} \mathrm{MeCN}$ was stirred at $80{ }^{\circ} \mathrm{C}$ for $24 \mathrm{~h}$. After it was cooled to room temperature, the solution was filtered through Celite. Then $\left[\mathrm{Ru}(p \text {-cymene }) \mathrm{Cl}_{2}\right]_{2}(153 \mathrm{mg}, 0.25 \mathrm{mmol})$ and $\mathrm{NH}_{4} \mathrm{PF}_{6}(163 \mathrm{mg}, 1.0 \mathrm{mmol})$ was added to the filtrate and stirred at reflux for $12 \mathrm{~h}$. The mixture was filtered through Celite to remove precipitated $\mathrm{NiCl}_{2}$ and all volatiles were evaporated under reduced pressure. The residue was washed with water and dried in vacuo. The yellow residue was dissolved in $\mathrm{MeCN}$ and concentrated to about $2 \mathrm{~mL}$. The addition of $\mathrm{Et}_{2} \mathrm{O}$ induced precipitation of the product as a yellow solid. Yield: $190 \mathrm{mg}, 53 \%$. Anal. calcd for $\mathrm{C}_{16} \mathrm{H}_{20} \mathrm{~F}_{12} \mathrm{~N}_{8} \mathrm{P}_{2} \mathrm{Ru}$ : C, 26.86; H, 2.82; N, 15.66; found: C, 26.70; H, 2.90; N, 15.58; ${ }^{1} \mathrm{H}$ NMR (400 MHz, DMSO- $\left.d_{6}\right) \delta 9.12\left(\mathrm{~d}, J=4.8 \mathrm{~Hz}, \mathrm{C}_{4} \mathrm{H}_{3} \mathrm{~N}_{2}\right.$, $1 \mathrm{H}), 8.85\left(\mathrm{~d}, J=4.8 \mathrm{~Hz}, \mathrm{C}_{4} \mathrm{H}_{3} \mathrm{~N}_{2}, 1 \mathrm{H}\right), 8.00(\mathrm{~d}, J=2.4 \mathrm{~Hz}$, $\left.\mathrm{C}_{3} \mathrm{H}_{2} \mathrm{~N}_{2}, 1 \mathrm{H}\right), 7.48$ (t, $\left.J=2.4 \mathrm{~Hz}, \mathrm{C}_{4} \mathrm{H}_{3} \mathrm{~N}_{2}, 1 \mathrm{H}\right), 7.36$ (d, $J=$ $\left.2.4 \mathrm{~Hz}, \mathrm{C}_{3} \mathrm{H}_{2} \mathrm{~N}_{2}, 1 \mathrm{H}\right), 4.04\left(\mathrm{~s}, \mathrm{CH}_{3}, 3 \mathrm{H}\right), 2.52,\left(\mathrm{~s}, \mathrm{CH}_{3} \mathrm{CN}, 3 \mathrm{H}\right)$, 2.12, $\left(\mathrm{s}, \mathrm{CH}_{3} \mathrm{CN}, 6 \mathrm{H}\right), 1.96,\left(\mathrm{~s}, \mathrm{CH}_{3} \mathrm{CN}, 3 \mathrm{H}\right) ;{ }^{13} \mathrm{C} \mathrm{NMR}$ (100 MHz, DMSO-d $\left.)_{6}\right) \delta 193.0$ (Ru-C), 180.9, 166.6, 158.4, 158.3, 157.4, 128.7, 125.7, 125.6, 117.7, 116.2, 35.8, 2.64, 2.20, 1.77 .

Synthesis of $\left[\mathrm{RuL2}\left(\mathrm{CH}_{3} \mathrm{CN}\right)_{3}\right]\left(\mathrm{PF}_{6}\right)_{2}(3)$. According to the same procedure as described for $\mathbf{2}$, complex $\mathbf{3}$ was obtained as a yellow soild. Yield: $249 \mathrm{mg}, 61 \%$. Anal. calcd for $\mathrm{C}_{29} \mathrm{H}_{31} \mathrm{~F}_{12} \mathrm{~N}_{9} \mathrm{P} 2 \mathrm{Ru}\left(\left[\mathrm{RuL} 2\left(\mathrm{CH}_{3} \mathrm{CN}\right)_{3}\right]\left(\mathrm{PF}_{6}\right)_{2}\right) \cdot 2 \mathrm{CH}_{3} \mathrm{CN}: \mathrm{C}$, 38.85; H, 3.48; N, 14.06; found: C, 38.70; H, 3.60; N, 14.08; ${ }^{1} \mathrm{H}$ NMR (400 MHz, DMSO- $\left.d_{6}\right) \delta 8.90\left(\mathrm{~d}, J=4.4 \mathrm{~Hz}, \mathrm{C}_{5} \mathrm{H}_{4} \mathrm{~N}\right.$, $2 \mathrm{H}), 8.11$ (t, $\left.J=6.4 \mathrm{~Hz}, \mathrm{C}_{5} \mathrm{H}_{4} \mathrm{~N}, 2 \mathrm{H}\right), 7.95-7.92\left(\mathrm{~m}, \mathrm{C}_{6} \mathrm{H}_{4}, 4 \mathrm{H}\right)$, $7.64\left(\mathrm{t}, J=5.2 \mathrm{~Hz}, \mathrm{C}_{5} \mathrm{H}_{4} \mathrm{~N}, 2 \mathrm{H}\right), 7.41-7.40\left(\mathrm{~m}, \mathrm{C}_{5} \mathrm{H}_{4} \mathrm{~N}, 2 \mathrm{H}\right)$, $5.85\left(\mathrm{~s}, \mathrm{CH}_{2}, 4 \mathrm{H}\right), 2.35$, (s, $\left.\mathrm{CH}_{3} \mathrm{CN}, 6 \mathrm{H}\right), 2.08\left(\mathrm{~s}, \mathrm{CH}_{3} \mathrm{CN}, 3 \mathrm{H}\right)$; ${ }^{13} \mathrm{C}$ NMR (100 MHz, DMSO- $\left.d_{6}\right) \delta 192.0(\mathrm{Ru}-C), 154.1,148.2$, $140.5,134.7,125.5,125.3,125.0,117.2,116.6,111.4,50.5$, $2.80,2.15$.

Synthesis of $\left[\mathrm{RuL1}\left(\mathrm{PPh}_{3}\right)\left(\mathrm{CH}_{3} \mathrm{CN}\right)_{3}\right]\left(\mathrm{PF}_{6}\right)_{2}$ (4). A mixture of $2(142 \mathrm{mg}, 0.2 \mathrm{mmol})$ and triphenylphosphine $(262 \mathrm{mg}$, $1.0 \mathrm{mmol}$ ) in $5 \mathrm{~mL} \mathrm{CH} \mathrm{CH}_{3} \mathrm{CN}$ was stirred at $80^{\circ} \mathrm{C}$ for $6 \mathrm{~h}$. Then the mixture was filtered through Celite and all volatiles were 
evaporated under reduced pressure. The residue was washed with ethyl acetate and dried in vacuo. The yellow residue was dissolved in $\mathrm{CH}_{3} \mathrm{CN}$ and crystallization by slow diffusion of $\mathrm{Et}_{2} \mathrm{O}$ into the $\mathrm{CH}_{3} \mathrm{CN}$ solution gave 4 as yellow solid. Yield: $75 \mathrm{mg}, 40 \%$. Anal. calcd for $\mathrm{C}_{32} \mathrm{H}_{32} \mathrm{~F}_{12} \mathrm{~N}_{7} \mathrm{P}_{3} \mathrm{Ru}$ : C, 41.04; H, 3.44; N, 10.47; found: C, 41.10; H, 3.40; N, 10.58; ${ }^{1} \mathrm{H}$ NMR (DMSO- $\left.d_{6}\right) \delta 8.99(\mathrm{~s}, 1 \mathrm{H}), 8.46(\mathrm{~s}, 1 \mathrm{H}), 8.38(\mathrm{~s}, 1 \mathrm{H})$, $7.87(\mathrm{~s}, 1 \mathrm{H}), 7.57(\mathrm{~s}, 13 \mathrm{H}), 7.42(\mathrm{~s}, 2 \mathrm{H}), 7.25(\mathrm{~s}, 1 \mathrm{H}), 4.11(\mathrm{~s}$, $3 \mathrm{H}), 2.14(\mathrm{~s}, 6 \mathrm{H}), 2.07(\mathrm{~s}, 3 \mathrm{H}) ;{ }^{13} \mathrm{C}$ NMR (DMSO- $\left.d_{6}\right) \delta 192.2$ (Ru-C), 183.8, 182.8, 163.4, 158.6, 157.9, 132.0, 131.9, 131.7, $131.5,129.0,128.7,127.9,127.6,127.5,127.4,127.2,127.1$, $126.3,125.5,117.9,116.4,116.3,35.8,2.15,1.72$.

Synthesis of [RuL1(Phen) $\left.\left(\mathrm{CH}_{3} \mathrm{CN}\right)_{2}\right]\left(\mathrm{PF}_{6}\right)_{2}$ (5). A mixture of $2(142 \mathrm{mg}, 0.2 \mathrm{mmol})$ and 1,10-phenanthroline $\cdot 1 \mathrm{H}_{2} \mathrm{O}(198 \mathrm{mg}$, $1.0 \mathrm{mmol}$ ) in $5 \mathrm{~mL} \mathrm{CH} \mathrm{CH}_{3} \mathrm{CN}$ was stirred at $80^{\circ} \mathrm{C}$ for $6 \mathrm{~h}$. Then the mixture was filtered through Celite to afford a yellow solution. Crystallization by slow diffusion of $\mathrm{Et}_{2} \mathrm{O}$ into the $\mathrm{CH}_{3} \mathrm{CN}$ solution gave 5 as an orange yellow solid. Yield: $103 \mathrm{mg}, 63 \%$. Anal. calcd for $\mathrm{C}_{24} \mathrm{H}_{22} \mathrm{~F}_{12} \mathrm{~N}_{8} \mathrm{P}_{2} \mathrm{Ru}$ : C, 35.43; H, 2.73; N, 13.77; found: C, 35.50; H, 2.90; N, 13.80; ${ }^{1} \mathrm{H}$ NMR (DMSO- $\left.d_{6}\right) \delta 9.77$ (dd, $J=1.2$ and $4.0 \mathrm{~Hz}, 1 \mathrm{H}), 9.08(\mathrm{dd}, J=0.8$ and $6.4 \mathrm{~Hz}, 1 \mathrm{H})$, $8.75(\mathrm{dd}, J=1.6$ and $4.0 \mathrm{~Hz}, 1 \mathrm{H}), 8.44-8.38(\mathrm{~m}, 3 \mathrm{H}), 8.32-8.29$ $(\mathrm{m}, 2 \mathrm{H}), 7.94(\mathrm{~d}, J=1.6 \mathrm{~Hz}, 1 \mathrm{H}), 7.73(\mathrm{dd}, J=4.4$ and $6.4 \mathrm{~Hz}$, $1 \mathrm{H}), 7.68(\mathrm{dd}, J=1.6$ and $6.4 \mathrm{~Hz}, 1 \mathrm{H}), 7.11(\mathrm{dd}, J=4.0$ and $4.4 \mathrm{~Hz}, 1 \mathrm{H}), 4.23$ (s, 3H), 4.22 (s, 3H), 2.53, 2.28 (s, $\mathrm{CH}_{3} \mathrm{CN}$, each $3 \mathrm{H}) ;{ }^{13} \mathrm{C}$ NMR (DMSO- $\left.d_{6}\right) \delta 192.3$ (Ru-C), 161.9, 159.9, 159.0, 157.5, 152.5, 148.0, 146.6, 138.8, 137.4, 130.9, 130.6,
$128.3,128.2,127.4,127.2,127.1,126.4,119.5,118.5,37.1$, $4.56,3.83,1.62$.

\section{Typical procedure for catalytic transfer hydrogenation reaction}

The ketone (1.0 mmol), KOH (0.2 mmol) and $2 \mathrm{~mL}$ of $\mathrm{iPrOH}$ were placed in a Schlenk tube. Anisole $(0.25 \mathrm{mmol})$ was added as an internal GC standard. The mixture was heated at $80{ }^{\circ} \mathrm{C}$ and then catalyst solution $(0.01 \mathrm{mmol}, 0.001 \mathrm{mmol}$, or $0.0001 \mathrm{~mol}$ of ruthenium complexes in $\mathrm{iPrOH}(1 \mathrm{~mL})$ was injected. Aliquots $(0.2 \mathrm{~mL})$ were taken at fixed time intervals, quenched with $1 \mathrm{~mL}$ of $\mathrm{H}_{2} \mathrm{O}$ and extracted with $3 \mathrm{~mL}$ of $\mathrm{Et}_{2} \mathrm{O}$. The product yields were determined by GC analysis.

\section{X-ray diffraction analysis}

Single-crystal X-ray diffraction data were collected at 298(2) K on a Siemens Smart-CCD area-detector diffractometer with a MoK $\alpha$ radiation $(\lambda=0.71073 \AA$ ) by using a $\omega-2 \theta$ scan mode. Unit-cell dimensions were obtained with least-squares refinement. Data collection and reduction were performed using the Oxford Diffraction CrysAlisPro software [44]. All structures were solved by direct methods, and the non-hydrogen atoms were subjected to anisotropic refinement by full-matrix least squares on $F^{2}$ using the SHELXTXL package [45]. Hydrogen atom positions for all of the structures were calculated and allowed to ride on their respective $\mathrm{C}$ atoms with $\mathrm{C}-\mathrm{H}$ distances of $0.93-0.97 \AA$ and $U_{\text {iso }}(\mathrm{H})=-1.2-1.5 U_{\text {eq }}(\mathrm{C})$. Details of the $\mathrm{X}$-ray experiments and crystals data are summarized in Table 3.

\begin{tabular}{|c|c|c|c|c|c|}
\hline & 1 & 2 & $3 \cdot 2 \mathrm{CH}_{3} \mathrm{CN}$ & $4 \cdot \mathrm{CH}_{3} \mathrm{CN}$ & 5 \\
\hline CCDC number & 1407422 & 1407423 & 1407424 & 1407425 & 1407426 \\
\hline Formula & $\begin{array}{c}\mathrm{C}_{20} \mathrm{H}_{22} \mathrm{~F}_{12} \mathrm{~N}_{10} \mathrm{P}_{2} \\
\mathrm{Ru}\end{array}$ & $\begin{array}{c}\mathrm{C}_{16} \mathrm{H}_{20} \mathrm{~F}_{12} \mathrm{~N}_{8} \mathrm{P}_{2} \\
\mathrm{Ru}\end{array}$ & $\begin{array}{c}\mathrm{C}_{29} \mathrm{H}_{31} \mathrm{~F}_{12} \mathrm{~N}_{9} \mathrm{P}_{2} \\
\mathrm{Ru}\end{array}$ & $\underset{\mathrm{Ru}}{\mathrm{C}_{34} \mathrm{H}_{35} \mathrm{~F}_{12} \mathrm{~N}_{8} \mathrm{P}_{3}}$ & $\begin{array}{c}\mathrm{C}_{24} \mathrm{H}_{22} \mathrm{~F}_{12} \mathrm{~N}_{8} \mathrm{P}_{2} \\
\mathrm{Ru}\end{array}$ \\
\hline$F W$ & 793.49 & 715.41 & 896.64 & 977.68 & 813.51 \\
\hline crystal system & Monoclinic & Monoclinic & Triclinic & Triclinic & Monoclinic, \\
\hline space group & $C 2 / c$ & $P 2 / n$ & $P-1$ & $P-1$ & $P 2_{1} / m$ \\
\hline$a, \AA$ & $23.240(3)$ & $11.2914(5)$ & $11.4695(12)$ & $9.9130(16)$ & $10.9570(8)$ \\
\hline$b, \AA$ & $10.3410(5)$ & $12.7244(6)$ & $13.1322(14)$ & $12.665(2)$ & $22.2567(16)$ \\
\hline$c, \AA$ & $16.060(4)$ & $21.4357(11)$ & $13.7721(14)$ & 2 18.222(3) & $16.8706(11)$ \\
\hline$\alpha$, deg & 90 & 90 & 97.7010 & 90 & 90 \\
\hline$\beta$, deg & $130.19(3)$ & $102.469(4)$ & 103.2130 & 90 & $97.384(6)$ \\
\hline Y, deg & 90 & 90 & 94.0570 & 66.96 & 90 \\
\hline$V, \AA^{3}$ & $2948.4(8)$ & $3007.2(2)$ & $1990.1(4)$ & 2105.2(6) & $4080.1(5)$ \\
\hline$Z$ & 4 & 4 & 2 & 2 & 4 \\
\hline$D_{\text {calcd }}, \mathrm{Mg} / \mathrm{m}^{3}$ & 1.788 & 1.580 & 1.496 & 1.542 & 1.324 \\
\hline Reflections collected & 5571 & 10931 & 15882 & 7390 & 15951 \\
\hline Reflections independent $\left(R_{\text {int }}\right)$ & $2597(0.0289)$ & $5299(0.0492)$ & $7002(0.0129)$ & $7390(0.0000)$ & $7385(0.0278)$ \\
\hline Goodness-of-fit on $F^{2}$ & 1.059 & 1.064 & 1.053 & 1.050 & 1.083 \\
\hline$R(I>2 \sigma l)$ & $0.0539,0.1465$ & $0.0712,0.2121$ & $0.0373,0.0973$ & $0.0418,0.1020$ & $0.0604,0.1788$ \\
\hline$R$ (all data) & $0.0617,0.1558$ & $0.0913,0.2322$ & $0.0389,0.0984$ & $0.0455,0.1049$ & $0.0794,0.1904$ \\
\hline
\end{tabular}




\section{Supporting Information}

Supporting Information File:

\section{Supporting Information File 1}

X-ray crystallographic data CCDC 1407422-1407426.

[http://www.beilstein-journals.org/bjoc/content/

supplementary/1860-5397-11-194-S1.cif]

\section{Acknowledgements}

This work was financially supported by the National Natural Science Foundation of Zhejiang Province (LQ14B020003).

\section{References}

1. Poyatos, M.; Mata, J. A.; Peris, E. Chem. Rev. 2009, 109, 3677-3707. doi:10.1021/cr800501s

2. Díez-González, S.; Marion, N.; Nolan, S. P. Chem. Rev. 2009, 109, 3612-3676. doi:10.1021/cr900074m

3. Hahn, F. E.; Jahnke, M. C. Angew. Chem., Int. Ed. 2008, 47, 3122-3172. doi:10.1002/anie.200703883

4. Edwards, P. G.; Hahn, F. E. Dalton Trans. 2011, 40, 10278-10288. doi:10.1039/c1dt10864f

5. Hock, S. J.; Schaper, L.-A.; Herrmann, W. A.; Kühn, F. E. Chem. Soc. Rev. 2013, 42, 5073-5089. doi:10.1039/c3cs60019j

6. Schaper, L.-A.; Hock, S. J.; Herrmann, W. A.; Kühn, F. E. Angew. Chem., Int. Ed. 2013, 52, 270-289. doi:10.1002/anie.201205119

7. Hopkinson, M. N.; Richter, C.; Schedler, M.; Glorius, F. Nature 2014, 510, 485-496. doi:10.1038/nature13384

8. Gradert, C.; Krahmer, J.; Sönnichsen, F. D.; Näther, C.; Tuczek, F. J. Organomet. Chem. 2014, 770, 61-68. doi:10.1016/j.jorganchem.2014.08.010

9. Galan, B. R.; Wiedner, E. S.; Helm, M. L.; Linehan, J. C.; Appel, A. M. Organometallics 2014, 33, 2287-2294. doi:10.1021/om500206e

10. Liu, B.; Pan, S.; Liu, B.; Chen, W. Inorg. Chem. 2014, 53, 10485-10497. doi:10.1021/ic501544d

11. Liu, B.; Liu, B.; Zhou, Y.; Chen, W. Organometallics 2010, 29 , 1457-1464. doi:10.1021/om100009u

12. Chen, C.; Qiu, H.; Chen, W. Inorg. Chem. 2011, 50, 8671-8678. doi:10.1021/ic2012233

13. Zhang, M.; Ni, X.; Shen, Z. Organometallics 2014, 33, 6861-6867. doi:10.1021/om500930m

14. Dang, L.; Guo, J.; Song, H.; Liu, B.; Wang, B. Dalton Trans. 2014, 43, 17177-17183. doi:10.1039/C4DT02198C

15. Borré, E.; Dahm, G.; Aliprandi, A.; Mauro, M.; Dagorne, S.; Bellemin-Laponnaz, S. Organometallics 2014, 33, 4374-4384. doi:10.1021/om5003446

16. Bierenstiel, M.; Cross, E. D. Coord. Chem. Rev. 2011, 255, 574-590. doi:10.1016/j.ccr.2010.10.040

17. Saha, B.; Sengupta, G.; Sarbajna, A.; Dutta, I.; Bera, J. K. J. Organomet. Chem. 2014, 771, 124-130. doi:10.1016/j.jorganchem.2013.12.051

18. Dakkach, M.; Fontrodona, X.; Parella, T.; Atlamsani, A.; Romero, I.; Rodríguez, M. Dalton Trans. 2014, 43, 9916-9923. doi:10.1039/C4DT00698D
19. Chung, L.-H.; Cho, K.-S.; England, J.; Chan, S.-C.; Wieghardt, K.; Wong, C.-Y. Inorg. Chem. 2013, 52, 9885-9896. doi:10.1021/ic4010196

20. Fernández, F. E.; Puerta, M. C.; Valerga, P. Organometallics 2011, 30, 5793-5802. doi:10.1021/om200665f

21. Corberán, R.; Mas-Marzá, E.; Peris, E. Eur. J. Inorg. Chem. 2009, 1700-1716. doi:10.1002/ejic.200801095

22. Normand, A. T.; Cavell, K. J. Eur. J. Inorg. Chem. 2008, 2781-2800. doi:10.1002/ejic.200800323

23. Horn, S.; Gandolfi, C.; Albrecht, M. Eur. J. Inorg. Chem. 2011, 2863-2868. doi:10.1002/ejic.201100143

24. DePasquale, J.; Kumar, M.; Zeller, M.; Papish, E. T. Organometallics 2013, 32, 966-979. doi:10.1021/om300547f

25. Yang, D.; Tang, Y.; Song, H.; Wang, B. Organometallics 2015, 34 2012-2017. doi:10.1021/acs.organomet.5b00256

26. Chen, C.; Zhang, Y.; Hong, S. H. J. Org. Chem. 2011, 76, 10005-10010. doi:10.1021/jo201756z

27. Semwal, S.; Ghorai, D.; Choudhury, J. Organometallics 2014, 33, 7118-7124. doi:10.1021/om500876k

28. Su, G.; Huo, X.-K.; Jin, G.-X. J. Organomet. Chem. 2012, 696, 533-538. doi:10.1016/j.jorganchem.2010.09.018

29. Wylie, W. N. O.; Lough, A. J.; Morris, R. H. Organometallics 2012, 31 , 2137-2151. doi:10.1021/om300108p

30. Naziruddin, A. R.; Huang, Z.-J.; Lai, W.-C.; Lin, W.-J.; Hwang, W.-S. Dalton Trans. 2013, 42, 13161-13171. doi:10.1039/C3DT51161H

31. Naziruddin, A. R.; Zhuang, C.-S.; Lin, W.-J.; Hwang, W.-S. Dalton Trans. 2014, 43, 5335-5342. doi:10.1039/C3DT53125B

32. Bernet, L.; Lalrempuia, R.; Ghattas, W.; Mueller-Bunz, H.; Vigara, L.; Llobet, A.; Albrecht, M. Chem. Commun. 2011, 47, 8058-8060. doi:10.1039/C1CC12615F

33. Liu, X.; Chen, W. Dalton Trans. 2012, 41, 599-608. doi:10.1039/C1DT11356A

34. Gu, S.; Liu, B.; Chen, J.; Wu, H.; Chen, W. Dalton Trans. 2012, 41, 962-970. doi:10.1039/C1DT11269D

35. Liu, X.; Chen, W. Organometallics 2012, 31, 6614-6622. doi:10.1021/om300644h

36. Liu, B.; Liu, X.; Chen, C.; Chen, C.; Chen, W. Organometallics 2012, 31, 282-288. doi:10.1021/om200881s

37. Wang, D.; Astruc, D. Chem. Rev. 2015, 115, 6621-6686. doi:10.1021/acs.chemrev.5b00203

38. Enthaler, S.; Jackstell, R.; Hagemann, B.; Junge, K.; Erre, G.; Beller, M. J. Organomet. Chem. 2006, 691, 4652-4659. doi:10.1016/j.jorganchem.2006.07.013

39. Danopoulos, A. A.; Winston, S.; Motherwell, W. B. Chem. Commun. 2002, 1376-1377. doi:10.1039/B202814J

40. Lai, Y.-B.; Lee, C.-S.; Lin, W.-J.; Naziruddin, A. R.; Hwang, W.-S Polyhedron 2013, 53, 243-248. doi:10.1016/j.poly.2013.01.042

41. Fernández, F. E.; Puerta, M. C.; Valerga, P. Organometallics 2012, 31 , 6868-6879. doi:10.1021/om300692a

42. Zhang, X.; Liu, B.; Liu, A.; Xie, W.; Chen, W. Organometallics 2009, 28 , 1336-1349. doi:10.1021/om800982r

43. Chen, C.; Qiu, H.; Chen, W. J. Organomet. Chem. 2012, 696, 4166-4172. doi:10.1016/j.jorganchem.2011.09.008

44. CrysAlisPro; Oxford Diffraction Ltd: Oxford, UK, 2008.

45. Sheldrick, G. M. SHELXS-97 and SHELXL-97, Program for X-ray crystal structure refinement, University of Göttingen: Göttingen, Germany, 1997. 


\section{License and Terms}

This is an Open Access article under the terms of the Creative Commons Attribution License

(http://creativecommons.org/licenses/by/2.0), which permits unrestricted use, distribution, and reproduction in any medium, provided the original work is properly cited.

The license is subject to the Beilstein Journal of Organic Chemistry terms and conditions:

(http://www.beilstein-journals.org/bjoc)

The definitive version of this article is the electronic one which can be found at:

doi:10.3762/bjoc. 11.194 